367580, г. Махачкала, просп. А. Акушинского, Научный городок.

Тел.: (8722)60-07-26; e-mail.ru: nizamivelijanov@ mail.ru.
Ключевые слова: итамбовые томаты; сорта томата; индекс плода; масса плода; число камер плода; морфологическое строение куста; диаметр стебля; доноры.

\title{
THE RESULTS OF THE TESTS OF NEW TOMATO standard VARIETIES IN CONDITIONS OF REPUBLIC OF DAGESTAN
}

Velizhanov Nizami Meylanovich, Candidate of Agricultural Sciences, Senior Researcher, Federal Agrarian Scientific Centre of Republic of Dagestan. Republic of Dagestan.

Keywords: standard tomatoes; tomato varieties; fetus index; fetal weight; number of cells of the fetus; morphological structure of stem diameter; bush donors.

Ten standard varieties, differing in the length of the stem were chosen in breeding and collector's gene pool of tomato. The aim was to study the experience of morphological and biological indicators of data, as well as donors and economically valuable traits for their further use in breeding of tomato. When examining samples the special attention was paid to such factors as the length of main stem, number of leaves on the main stem, number of flowers in a third brush number of side stems, stem diameter at the base, the diameter of the stem above the third leaf. After three years of experiments in studying the morphological and biological indicators of standard tomato varieties prospective donors have been allocated: Torpedo, Gigantskaya Rosa, L20/11, Phonarik. These varieties characterize by a unique combination of agronomic characteristics and can be used as a parent form to obtain high-value hybrid.

\section{ВЛИЯНИЕ МИКРОБИОЛОГИЧЕСКОГО УДОБРЕНИЯ И ГУСТОТЫ СТОЯНИЯ РАСТЕНИЙ НА УРОЖАЙНОСТЬ ЗЕРНА ГИБРИДОВ КУКУРУЗЫ В НИЖНЕМ ПОВОЛЖЬЕ}

\author{
ГУДОВА Людмила Александровна, РосНИИСК «Россорго» \\ ЖУЖУкИН Валерий Иванович, Саратовский государственный аграрный университет \\ имени Н.И. Вавилова
}

ЗАЙЦЕВ Сергей Александрович, РосНИИСК «Россорго»

ВоЛКОВ Дмитрий Петрович, РосНИИСК «Россорго»

ГЕРАСКИНА Анастасия Александровна, Саратовский государственный аграрный университет имени Н.И. Вавилова

Представлены результаты исследований трехфакторного опыта, позволяющего определить влияния микробиологического удобрения Экстрасол (фактор С) и густоты стояния растения (фактор В) на урожайность гибридов кукурузы (фактор А). Установлено, что в условиях 2014 г. более высокую среднюю урожайность сформировал раннеспелый гибрид Росс 197 МВ - 5,46 m/2a. В 2015 и 2016 г. более продуктивным оказался гибрид среднеранней группы спелости Росс 299 МВ с урожайностью зерна 6,85 и 5,97 m/2a соответственно. Среднепоздний гибрид СТК 175 МВ в условиях эксперимента не реализовал потенциальную урожайность вследствие дефицита влаги в период вегетации. У гибридов прослеживается тенденция увеличения урожайности зерна при возрастании числа растений на единииу площади. Урожайность зерна по фактору В составила в 2014 2. 3,23-7,25 m/ra; в 2015 2. -3,80-8,41 m/2a; в 2016 2. - 3,91-6,19 m/2a. Haибольшее влияние на изменчивость признака «урожайность зерна» в 2014 и 2015 г. оказал фактор В (густота стояния растений) - 79,0 и 82,30 \% соответственно. В 2016 г. влияние фактора В было несколько ниже - 47,0 \%, но одновременно возрасло влияние фактора А (гибрид) - 33,6\%.

Введение. В настоящее время кукуруза является одной из самых востребованных сельскохозяйственных культур, еe хозяйственная ценность связана с высокой потенциальной продуктивностью и многосторонним использованием. Кукурузе свойственна значительная генетически обусловленная изменчивость хозяйственно-ценных признаков и свойств, что является ресурсом для адаптации культуры в широком диапазоне условий выращива- ния $[8,9,11,13]$. Биологические требования кукурузы в агроценозе могут значительно варьировать, что обусловлено изменением комплекса коррелирующих физиолого-биохимических свойств и морфологических признаков [15]. Для формирования высокой и стабильной урожайности зерна кукуруза потребляет значительное количество питательных веществ. Перспективным приемом обеспечения потребности растений в азоте, может быть использование пре- 
паратов ризосферных диазотрофов [1, 5-7]. Биопрепараты и микроудобрения, применяемые при предпосевной обработке семян и опрыскивании растений в период вегетации, попадая в почву, оказывают воздействие на деятельность живых организмов, которые положительно влияют на плодородие почвы, рост и развитие растений, урожай и качество продукции $[2,5,16-19]$.

При разработке технологии возделывания кукурузы важное значение уделяется определению оптимальной нормы высева. Установлено, что в загущенных посевах медленнее идут процессы формирования генеративных органов, удлиняется продолжительность вегетационного периода. Оптимальное число растений на единицу площади способствует более полному использованию природных и антропогенных факторов произрастания культуры. По литературным данным густота стояния растений оказывает на урожай большее влияние, чем внесение удобрений $[3,12,16]$.

Методика исследований. На опытном поле ФГБНУ РосНИИСК «Россорго» в 20142016 гг. изучали влияние микробиологического удобрения Экстрасол на урожайность зерна гибридов кукурузы разных групп спелости. Опыт заложили по трехфакторной схеме. Фактор А - гибриды кукурузы: А - Росс 197 МВ (раннеспелый), А - Росс 299 МВ (среднеранний), A $_{3}$ - СТК 175 (среднепоздний); фактор В - число растений на единицу площади: $\mathrm{B}_{1}-25,0 ; \mathrm{B}_{2}-35,0 ; \mathrm{B}_{3}-45,0$ (рекомендуемая); $\mathrm{B}_{4}-55,0 ; \mathrm{B}_{5}-65,0$ тыс. шт. раст. /га соответственно; фактор C - варианты обработки микробиологическим удобрением Экстрасол: $\mathrm{C}_{1}$ - без обработки (контроль), $\mathrm{C}_{2}$ - обработка вегетирующих растений в фазу 4-5 листьев, $\mathrm{C}_{3}$ - обработка вегетирующих растений в фазу 4-5 листьев и дополнительно через 10 дней, $\mathrm{C}_{4}$ - обработка семенного материала, $\mathrm{C}_{5}$ - обработка семян и вегетирующих растений в фазу 4-5 листьев, $\mathrm{C}_{6}$ - обработка семян и вегетирующих растений в фазу 4-5 листьев и дополнительно через 10 дней. Полевой опыт заложен методом расщепленных делянок и блоков. Площадь делянок - 15,4 м². Повторность - трехкратная. Посев проводили: в 2014 г. 22 мая, в 2015 г. 18 мая, в 2016 г. 29 мая. Агротехника возделывания - зональная. Густоту стояния растений формировали вручную в фазу 2-3 листьев. Исследования в опыте выполняли в соответствии с положениями рекомендаций по проведению полевых опытов с кукурузой [10]. Статистическая обработка результатовисследованийвыполненапометодики Б.А. Доспехова [4].

Обработку семян проводили раствором Экстросола (жидкая форма) из расчета 1 л пре- парата на 1 т семян. Обработку вегетирующих растений проводили из расчета 2 л/га препарата с расходом рабочего раствора 300 л/га (0,3 л на $\left.10 \mathrm{M}^{2}\right)$ [14].

Микробиологическое удобрение Экстрасол разработано ВНИИ сельскохозяйственной микробиологии РАСХН (производитель ООО «Бисолби-Интер»). Он представляет собой препарат ризосферных азотофиксирующих бактерий Bacillus subtilis штамм Ч-13. Состав препарата: вегетативные клетки $<10$ \%, споровая культура $>90 \%$ (от общего числа клеток) и продукты бактериального метаболизма: антибиотики, ферменты, фитогормоны, витамины и т.д. [19].

Гидротермический коэффициент за период вегетации кукурузы (май-сентябрь) составил: 2014 г. - 0,48; 2015 г. - 0,52; 2016 г. - 0,73.

Результаты исследований. В 2014 г. наибольшая средняя урожайность зерна по фактору А выявлена у раннеспелого гибрида Росс 197 МВ и среднепозднего гибрида СТК 175 - 5,46и 5,38 т/га соответственно. У среднеспелого гибрида Росс 299 МВ урожайность зерна была существенно ниже и составила 5,12 т/га (табл. 1).

Урожайность зерна по фактору В составила 3,23 т/га $\left(\mathrm{B}_{1}\right)-7,25$ т/га $\left(\mathrm{B}_{6}\right)$. У гибридов прослеживалась тенденция увеличения урожайности зерна при возрастании числа растений на единицу площади. Так, при изменении густоты стояния растений от 25,0 тыс. шт. растений/га до 35,0 тыс. шт. растений/га прибавка урожайности у гибрида Росс 197 МВ составила 0,94-1,70 т/га, у гибрида Росс 299 MB - 0,23-2,0 т/га; у СТК 175 МB 0,442,09 т/га. При увеличении густоты стояния растений кукурузы от 35,0 тыс. шт. раст./га до 45,0 тыс. шт. раст./га урожайность зерна у гибрида Росс 197 МВ находился на уровне - 0,58-0,93 т/га; уРосс 299 МВ - 0,311,92 т/га, у СТК 175 МВ - 0,01-2,17 т/га. Изменение густоты стеблестоя от 45,0 тыс. шт. раст./га до 55,0 тыс. шт. раст./га способствовало росту урожайности гибрида Росс $197 \mathrm{MB}$ от 0,08 до 1,69 т/га, Росс $299 \mathrm{MB}-$ от 0,05 до 1,98 т/га, СТК 175 МВ - от 0,15 до 2,12 т/га. Загущение посевов кукурузы от 55,0 тыс. шт. раст./га до 65,0 тыс. раст./га у гибрида Росс 197 МВ выявило повышение урожайности на 0,12-3,25 т/га, у Росс 299 МВ на 0,091,15 т/га, у СТК 175 MB на 0,37-2,02 т/га.

Урожайность по фактору С в зависимости от варианта обработки микробиологическим удобрением Экстрасол в 2014 г. колебалась от 5,30 до 5,53 т/га. Самая высокая урожайность была установлена при опрыскивании посевов в фазу 4-5 листьев $\left(\mathrm{C}_{2}\right)$, а самая низкая при обработке семян и вегетирующих растений в фазу 4-5 листьев $\left(\mathrm{C}_{5}\right)$. Урожайность зерна на варианте $\mathrm{C}_{1}$ 
Урожайность зерна гибридов кукурузы, обработанных микробиологическим удобрением Экстрасол, при разной густоте стояния растений, 2014 г. (т/га)

\begin{tabular}{|c|c|c|c|c|c|c|}
\hline \multirow[t]{2}{*}{ Гибриды (А) } & \multirow{2}{*}{$\begin{array}{l}\text { Вариант обра- } \\
\text { ботки (C) }\end{array}$} & \multicolumn{5}{|c|}{$\begin{array}{l}\text { Число растений на единицу площади (В), } \\
\text { тыс. шт. раст./ га }\end{array}$} \\
\hline & & $25\left(B_{1}\right)$ & $35\left(\mathrm{~B}_{2}\right)$ & $45\left(\mathrm{~B}_{3}\right)$ & $55\left(\mathrm{~B}_{4}\right)$ & $65\left(B_{5}\right)$ \\
\hline \multirow{6}{*}{ Pocc $197 \mathrm{MB}\left(\mathrm{A}_{1}\right)$} & $\mathrm{C}_{1}$ & 3,23 & 4,17 & 5,10 & 6,79 & 7,10 \\
\hline & $\mathrm{C}_{2}$ & 3,41 & 5,81 & 6,38 & 6,65 & 9,66 \\
\hline & $\mathrm{C}_{3}$ & 3,92 & 5,62 & 6,24 & 7,10 & 6,83 \\
\hline & $\mathrm{C}_{4}$ & 2,74 & 4,04 & 4,62 & 5,02 & 6,67 \\
\hline & $\mathrm{C}_{5}$ & 3,21 & 4,73 & 4,41 & 5,91 & 5,79 \\
\hline & $\mathrm{C}_{6}$ & 3,13 & 4,75 & 5,55 & 5,63 & 8,88 \\
\hline \multirow{6}{*}{$\begin{array}{l}\text { Pocc } 299 \mathrm{MB} \\
\left(\mathrm{A}_{2}\right)\end{array}$} & $\mathrm{C}_{1}$ & 2,70 & 4,70 & 5,50 & 5,55 & 5,71 \\
\hline & $\mathrm{C}_{2}$ & 3,80 & 4,60 & 4,91 & 5,28 & 6,43 \\
\hline & $\mathrm{C}_{3}$ & 3,62 & 3,90 & 4,89 & 5,88 & 6,41 \\
\hline & $\mathrm{C}_{4}$ & 3,23 & 3,46 & 5,38 & 6,12 & 8,20 \\
\hline & $\mathrm{C}_{5}$ & 3,31 & 4,61 & 5,12 & 7,10 & 7,01 \\
\hline & $\mathrm{C}_{6}$ & 2,82 & 3,63 & 5,25 & 6,47 & 7,33 \\
\hline \multirow{6}{*}{ СТК $175 \mathrm{MB}\left(\mathrm{A}_{3}\right)$} & $\mathrm{C}_{1}$ & 3,13 & 5,02 & 5,28 & 7,40 & 7,77 \\
\hline & $\mathrm{C}_{2}$ & 3,60 & 4,04 & 5,31 & 5,52 & 7,21 \\
\hline & $\mathrm{C}_{3}$ & 3,10 & 3,71 & 5,88 & 5,73 & 7,50 \\
\hline & $\mathrm{C}_{4}$ & 3,65 & 4,31 & 4,41 & 5,88 & 7,90 \\
\hline & $\mathrm{C}_{5}$ & 2,73 & 4,82 & 5,26 & 7,21 & 7,76 \\
\hline & $\mathrm{C}_{6}$ & 2,90 & 4,79 & 4,79 & 7,41 & 6,53 \\
\hline$F_{\text {факт. }}$ & \multicolumn{6}{|c|}{$\mathrm{A}=79,65^{*} ; \mathrm{B}=2310,92^{*} ; \mathrm{C}=27,99^{*} ; \mathrm{AB}=13,92^{*} ; \mathrm{AC}=99,28^{*} ; \mathrm{BC}=33,16^{*} ; \mathrm{ABC}=32,51^{*}$} \\
\hline $\mathrm{HCP}_{05}$ & \multicolumn{6}{|c|}{$\begin{array}{c}\mathrm{A}=0,07 ; \mathrm{B}=0,16 ; \mathrm{C}=0,08 ; \\
\mathrm{AB}=0,09 ; \mathrm{AC}=0,15 ; \mathrm{BC}=0,19 ; \mathrm{ABC}=0,32\end{array}$} \\
\hline \multicolumn{7}{|c|}{ Среднее по фактору А: $\mathrm{A}_{1}=5,46 c ; \mathrm{A}_{2}=5,12 a ; \mathrm{A}_{3}=5,38 b ;$} \\
\hline \multicolumn{7}{|c|}{ Среднее по фактору В: $\mathrm{B}_{1}=3,23 a ; \mathrm{B}_{2}=4,53 b c ; \mathrm{B}_{3}=5,23 b ; \mathrm{B}_{4}=6,35 d ; \mathrm{B}_{5}=7,26 e$; } \\
\hline \multicolumn{7}{|c|}{ Среднее по фактору С: $\mathrm{C}_{1}=5,20 b c ; \mathrm{C}_{2}=5,53 d ; \mathrm{C}_{3}=5,38 c ; \mathrm{C} 4=5,06 a ; \mathrm{C}_{5}=5,29 b ; \mathrm{C} 6=5,34 b c$} \\
\hline
\end{tabular}

Примечание: множественные сравнения частных средних по критерию Дункана (одинаковые буквы указывают на отсутствие различий).

(без обработки) составила 5,30 т/га. По критерию Дункана отличия по урожайности зерна отсутствуют между вариантами $\mathrm{C}_{1}, \mathrm{C}_{3}, \mathrm{C}_{6}$.

При густоте стояния 25,0 тыс. шт. раст./га прибавка выявлена на вариантах $\mathrm{C}_{2}$ и $\mathrm{C}_{3}$ в размере 0,18 и 0,69 т/га. Варианты обработки $\mathrm{C}_{2}, \mathrm{C}_{3}, \mathrm{C}_{5}, \mathrm{C}_{6}$ обеспечили увеличение урожайности при густоте 35,0 тыс.шт.раст./га (0,56-1,45т/га).Пригустоте 45 тыс. шт. раст./га более эффективным оказалисьварианты $\mathrm{C}_{2}, \mathrm{C}_{3}, \mathrm{C}_{6}$,урожайностьповысиласьна 0,45-1,28т/га. Сувеличениемгустотыдо 55,0 тыс. шт. раст./га положительный эффект установлен только при двухкратной обработке вегетирующих растений $\left(\mathrm{C}_{3}\right)$, прибавка 0,31 т/га. При максимальной густоте стояния растений урожайность повысилась при обработке вегетирующих растений в фазу 4-5 листьев $\left(\mathrm{C}_{2}\right)$ и при обработке семян в сочетании с двукратной обработкой вегетирующих растений $\left(\mathrm{C}_{6}\right)$ на 2,56 и 1,78 т/га соответственно.
Обработка семян на варианте $\mathrm{C}_{4}$ микробиологическим препаратом Экстрасол оказалась неэффективной для увеличения урожайности зерна гибрида Росс 197 МВ.

Применение микробиологического удобрения на гибриде среднеранней группы спелости Росс 299 МВ было эффективно на 13 вариантах, причем на минимальной (25,0 тыс. шт. раст./га - 4 варианта) и максимальных густотах (55,0 тыс. шт. раст./га 4, 65,0 тыс. шт. раст./га - 5 вариантов). Так, при густоте стояния растений 25,0 тыс. шт. раст./га наиболее эффективными оказались варианты обработки $\mathrm{C}_{2}, \mathrm{C}_{3}, \mathrm{C}_{4}, \mathrm{C}_{5}$, прибавка составила 0,53-1,1 т/га. При густоте 55,0 тыс. шт. раст./га варианты обработки $\mathrm{C}_{3}, \mathrm{C}_{4}, \mathrm{C}_{5}, \mathrm{C}_{6}$ обеспечили увеличение урожайности на 0,331,55 т/га относительно контроля. При густоте 65,0 тыс. шт. раст./га отмечается положительный эффект от применения Экстрасола независимо от числа и способа обработки. Максимальную урожайность обеспечил вариант 
$\mathrm{C}_{4}(8,20$ т/га), что было на 2,49 т/га выше варианта $\mathrm{C}_{1}$

Обработка семян и вегетирующих растений микробиологическим удобрением среднепозднего гибрида СТК 175 MB позволила повысить урожайность зерна только на шести вариантах. Варианты обработки $\mathrm{C}_{2}$ и $\mathrm{C}_{4}$ при густоте 25,0 тыс. шт. раст./га обеспечили прибавку в 0,470,52 т/га. При густоте 45,0 тыс. шт. раст./га варианты $\mathrm{C}_{2}, \mathrm{C}_{3}$ привели к повышению урожайности на 0,03-0,6 т/га. Варианты обработки $\mathrm{C}_{6}$ и $\mathrm{C}_{4}$ оказались эффективными при густотах 55,0 и 65,0 тыс. шт. раст./га соответственно.

В условиях 2014 г. наибольшее влияние на изменчивость признака «урожайность зерна» оказал фактор В (густота стояния растений) $79,0 \%$, существенно ниже значения факторов А и С - 0,86 и 0,07 \% соответственно. На изменение урожайности зерна взаимодействие факторов составило: ВС - 3,68 \%, АC - 5,5\%, $\mathrm{AB}-0,75 \%$ и $\mathrm{ABC}-0,26 \%$.

Погодные условия, сложившиеся в период вегетации 2015 г., способствовали формированию высокой урожайности зерна гибридов кукурузы. Урожайность зерна по фактору А изменялась от 6,20 до 6,85 т/га. Гибрид кукурузы среднеранней группы спелости сформировал более высокую среднюю урожайность - 6,85 т/га. Урожайность раннеспелого гибрида Росс 197 МВ и среднепозднего СТК 175 МВ была ниже на 0,43 и 0,65 т/га соответственно (табл. 2).

Интервал варьирования частных средних по фактору В составил 3,80-8,41 т/га. При увеличении густоты стояния с 25,0 тыс. шт. раст./га до 35,0 тыс. шт. раст./га наблюдалось значительное повышение урожайности зерна у гибридов кукурузы: на 1,1-2,33 т/га у Росс 197 МВ и на 1,73-3,46 т/га у Росс 299 МВ. У среднепозднего гибрида СТК 175 МВ прибавка была несколько ниже - 0,47-1,8 т/га.

Повышение густоты стеблестоя с 35,0 тыс. шт. раст./га до 45,0 тыс. шт. раст. /га способствовало росту урожайности зерна на 1,17-2,37 т/га у гибрида Росс $197 \mathrm{MB}$, на 0,41,7 т/га у гибрида Росс $299 \mathrm{MB}$ и 0,562,62 т/га у СТК 175 МВ. С дальнейшим повышением числа растений на единицу площади до 55,0 тыс. шт. раст./га прибавка урожайности составила 0,63-1,56 т/гау гибрида Росс 197 MB; 0,10,91 т/га у гибрида Росс 299 MB; 0,24-2,35 т/га у СТК 175 МВ. При загущении посева до 65,0 тыс. шт. раст./га прибавка урожая составила 0,491,82 т/га у раннеспелого гибрида (Росс $197 \mathrm{MB})$; 0,31-2,12 т/га у среднераннего (Росс 299 МВ), а у среднепозднего гибрида (СТК $175 \mathrm{MB}$ ) наблюдалось снижение урожайности на 0,09-0,93 т/га.

Средняя урожайность по фактору С изменялась от 6,18 до 6,66 т/га, низкий показатель соответствовал варианту $\mathrm{C}_{1}$, высокий - вари- анту $\mathrm{C}_{6}$. Достоверных отличий не зафиксировано между вариантами $\mathrm{C}_{3}, \mathrm{C}_{4}, \mathrm{C}_{5}$

При густоте 25,0 тыс. шт. раст./га прибавка былавыявлена на вариантах $\mathrm{C}_{2}, \mathrm{C}_{3}, \mathrm{C}_{4}, \mathrm{C}_{5}$ и составила 0,05-0,35т т/га. Варианты обработки $\mathrm{C}_{2}$, $\mathrm{C}_{5}, \mathrm{C}_{6}$ были эффективными при густоте 35,0 тыс. шт. раст./га, урожайность увеличилась на 0,260,32 т/га. При густоте стояния до 55,0 тыс. шт. раст./га применение микробиологического удобрения повысило урожайность в вариантах $\mathrm{C}_{2}, \mathrm{C}_{3}, \mathrm{C}_{4}, \mathrm{C}_{5}$ на 0,23-0,75 т/га. Влияние Экстрасола на повышенной густоте установили на вариантах $\mathrm{C}_{2}, \mathrm{C}_{3}, \mathrm{C}_{4}$ в размере $0,79-3,07$ т/га. На густоте 45,0 тыс. шт. раст./га положительный эффект отсутствовал, урожайность контрольного варианта была выше на 0,44-1,27 т/га.

Применение микробиологического удобрения на гибриде среднеспелой группы Росс 299 МВ выявило его эффективность на 14 вариантах. Так, при густоте 35,0 тыс. шт. раст./га варианты обработки $\mathrm{C}_{2}$ и $\mathrm{C}_{4}$ обеспечили увеличение урожайности зерна на 0,22 и 1,27 т/га относительно контроля. При густоте 45,0 тыс. шт. раст./га все варианты обработок были эффективными, прибавка колебалась от 0,04 до 1,77 т/га. На четырех вариантах использования Экстрасола $\left(\mathrm{C}_{2}, \mathrm{C}_{3}, \mathrm{C}_{4}, \mathrm{C}_{6}\right)$ при густоте 55,0 тыс. шт. раст./га выявлен положительный результат, увеличение урожайности составило 0,8-1,27 т/га. На самой высокой густоте стояния растений(65,0 тыс. шт. раст./га) варианты обработки $\mathrm{C}_{2}, \mathrm{C}_{3}, \mathrm{C}_{4}$ способствовали повышению урожайности относительно контроля на $0,47-1,48$ т/га.

На посевах среднепозднего гибрида СТК 175 МВ применение Экстрасола проявилось на 17 вариантах. При плотности посева 25,0 тыс. шт. раст./га увеличение урожайности отмечено на всех вариантах, где применяли микробиологическое удобрение. Прибавка составила $0,33-0,99$ т/га.

На посеве с густотой 35,0 тыс. шт. раст./га урожайность выше контроля отмечена в двух случаях $\left(\mathrm{C}_{5}, \mathrm{C}_{6}\right)$. Варианты обработки $\mathrm{C}_{2}$ и $\mathrm{C}_{4}$ способствовали повышению урожайности гибрида СТК $175 \mathrm{MB}$ на густоте 45,0 тыс. раст./га. Прибавка урожайности составила 0,6 и 0,24 т/га соответственно. При густоте 55,0 тыс. шт. раст./га увеличение урожайности отмечалось на вариантах $\mathrm{C}_{2}, \mathrm{C}_{3}, \mathrm{C}_{4}, \mathrm{C}_{6}$ от 0,26 до 2,0 т/га. При максимальной густоте стояния эффективность действия микробиологического препарата отмечалось на всех вариантах его применения. Урожайность относительно контроля увеличилась на $0,52-2,43$ т/га.

Следует отметить высокое влияние фактора В (густота стояния растений) на изменчивость признака «урожайность зерна» - 82,30 \%. Вклад факторов А и С в общую изменчивость 
Урожайность зерна гибридов кукурузы, обработанных микробиологическим удобрением Экстрасол, при разной густоте стояния растений, 2015 г. (т/га)

\begin{tabular}{|c|c|c|c|c|c|c|}
\hline \multirow{2}{*}{ Гибриды (А) } & \multirow{2}{*}{$\begin{array}{l}\text { Вариант обра- } \\
\text { ботки (C) }\end{array}$} & \multicolumn{5}{|c|}{$\begin{array}{c}\text { Число растений на единицу площади (В), } \\
\text { тыс. шт. раст./га }\end{array}$} \\
\hline & & $25\left(\mathrm{~B}_{1}\right)$ & $35\left(\mathrm{~B}_{2}\right)$ & $45\left(\mathrm{~B}_{3}\right)$ & $55\left(\mathrm{~B}_{4}\right)$ & $65\left(\mathrm{~B}_{5}\right)$ \\
\hline \multirow{6}{*}{ Pocc 197 MB $\left(A_{1}\right)$} & $\mathrm{C}_{1}$ & 3,49 & 5,21 & 7,58 & 7,48 & 6,98 \\
\hline & $\mathrm{C}_{2}$ & 3,63 & 5,47 & 6,31 & 7,71 & 8,34 \\
\hline & $\mathrm{C}_{3}$ & 3,84 & 4,94 & 6,67 & 7,85 & 7,77 \\
\hline & $\mathrm{C}_{4}$ & 3,54 & 4,90 & 6,67 & 8,23 & 10,05 \\
\hline & $\mathrm{C}_{5}$ & 3,81 & 5,53 & 7,14 & 7,82 & 8,91 \\
\hline & $\mathrm{C}_{6}$ & 3,18 & 5,51 & 6,68 & 7,31 & 8,95 \\
\hline \multirow{6}{*}{$\begin{array}{l}\text { Pocc } 299 \mathrm{MB} \\
\left(\mathrm{A}_{2}\right)\end{array}$} & $\mathrm{C}_{1}$ & 3,99 & 6,16 & 6,56 & 7,04 & 8,94 \\
\hline & $\mathrm{C}_{2}$ & 3,50 & 6,38 & 7,08 & 7,18 & 9,51 \\
\hline & $\mathrm{C}_{3}$ & 3,75 & 6,06 & 7,00 & 8,30 & 10,42 \\
\hline & $\mathrm{C}_{4}$ & 3,97 & 7,43 & 8,33 & 8,67 & 9,41 \\
\hline & $\mathrm{C}_{5}$ & 3,77 & 5,50 & 6,90 & 6,71 & 7,06 \\
\hline & $\mathrm{C}_{6}$ & 3,92 & 5,95 & 7,65 & 8,56 & 8,87 \\
\hline \multirow{6}{*}{ СТК $175 \mathrm{MB}\left(\mathrm{A}_{3}\right)$} & $\mathrm{C}_{1}$ & 3,44 & 5,24 & 6,80 & 6,69 & 6,60 \\
\hline & $\mathrm{C}_{2}$ & 4,31 & 4,78 & 7,40 & 6,95 & 9,03 \\
\hline & $\mathrm{C}_{3}$ & 3,77 & 5,16 & 6,34 & 8,69 & 8,26 \\
\hline & $\mathrm{C}_{4}$ & 3,96 & 5,14 & 5,70 & 7,38 & 7,12 \\
\hline & $\mathrm{C}_{5}$ & 4,17 & 5,25 & 6,09 & 6,33 & 7,78 \\
\hline & $\mathrm{C}_{6}$ & 4,43 & 5,47 & 7,04 & 8,39 & 7,46 \\
\hline$F_{\text {факт. }}$ & \multicolumn{6}{|c|}{$\mathrm{A}=591,08^{*} ; \mathrm{B}=2986,75^{*} ; \mathrm{C}=118,24^{*} ; \mathrm{AB}=34,56^{*} ; \mathrm{AC}=107,72^{*}, \mathrm{BC}=51,18^{*}, \mathrm{ABC}=50,425^{*}$} \\
\hline $\mathrm{HCP}_{05}$ & \multicolumn{6}{|c|}{$\mathrm{A}=0,05 ; \mathrm{B}=0,09, \mathrm{C}=0,06 ; \mathrm{AB}=0,16 ; \mathrm{AC}=0,10 ; \mathrm{BC}=0,15 ; \mathrm{ABC}=0,26$} \\
\hline \multicolumn{7}{|c|}{ Среднее по фактору A: $\mathrm{A}_{1}=6,42 \mathrm{~b} ; \mathrm{A}_{2}=6,85 \mathrm{c} ; \mathrm{A}_{3}=6,20 \mathrm{a}$} \\
\hline \multicolumn{7}{|c|}{ Среднее по фактору В: $\mathrm{B}_{1}=3,80 a ; \mathrm{B}_{2}=5,61 b ; \mathrm{B}_{3}=6,88 c ; \mathrm{B}_{4}=7,74 d ; \mathrm{B}_{6}=8,41 e$} \\
\hline \multicolumn{7}{|c|}{ Среднее по фактору С: $\mathrm{C}_{1}=46,18 a ; \mathrm{C}_{2}=6.54 b ; \mathrm{C}_{3}=6.62 c d ; \mathrm{C}_{4}=6,73 e ; \mathrm{C}_{5}=6,21 a ; \mathrm{C}_{6}=6,66 d$} \\
\hline
\end{tabular}

признака составил 2,24 и $1,43 \%$ соответственно, а взаимодействие факторов: АС - 2,61 \%, $\mathrm{BC}-2,48 \%, \mathrm{AB}-1,90 \%, \mathrm{ABC}-4,89 \%$.

В 2016 г. самую высокую урожайность по фактору А сформировал гибрид Росс 299 МВ 5,99 т/га. Урожайность раннеспелого гибрида Росс 199 МВ и среднепозднего СТК 175 МВ ниже на 0,82 т/га и 1,64 т/га соответственно (табл. 3).

Как и в предыдущие годы исследований, наблюдается тенденция увеличения урожайности по мере возрастания числа растений на единице площади как на варианте без применения, так и на вариантах с применением микробиологического удобрения Экстрасол. Так, урожайности изменялась в зависимости от густоты стояния растений от 3,91 до 6,19 т/га.

На посевах гибрида Росс 197 МВ средняя урожайность при 25,0 тыс. шт. раст. га составила 3,93 т/га. Увеличение густоты стояния до 35,0 тыс. шт. раст. га способствовало увеличению урожайности на 0,40-1,23 т/га. Густота 45,0 тыс. шт. раст./га обеспечила прибавку 0,19-0,93 т/га. При повышении числа растений до 55,0 тыс. шт. раст./га и 65,0 тыс. шт. раст./га наблюдался рост урожайности от 0,12 до 1,26 т/га и от 0,83 до 2,50 т/га соответственно.

При увеличении густоты стояния гибрида Росс 299 МВ от 25,0 тыс. шт. раст./га 35,0 тыс. шт. раст./га прибавка урожайности составила 0,70-2,08 т/га. Увеличение числа растений на единицу площади еще на 10 тыс. шт. (45 тыс. шт. раст./га) обеспечило прибавку 0,25-1,07 т/га. При достижении густоты стояния 55,0 тыс. шт. раст./га и 65,0 тыс. шт. раст./га урожайность увеличилась на 0,110,45 т/га и 0,50-0,89 т/га.

Увеличение урожайности зерна у среднепозднего гибрида СТК 175 МВ в зависимости от варианта обработки Экстрасолом более четко выражено при повышении густоты стояния с 25,0 тыс. шт. раст./га до 45,0 тыс. шт. раст./га и с 45,0 тыс. шт. раст./га до 55,0 тыс. шт. раст./га, 0,059-2,28 т/га и 0,211,38 т/га соответственно.

Применение микробиологического удобрения на раннеспелом гибриде Росс 197 МВ в разных сочетаниях обеспечило эффект на в 7 вариантах из 30 , из них $\mathrm{C}_{2}, \mathrm{C}_{3}, \mathrm{C}_{5}$ при густоте 25,0 
Урожайность зерна гибридов кукурузы, обработанных микробиологическим удобрением Экстрасол, при разной густоте стояния растений, 2016 г. (т/га)

\begin{tabular}{|c|c|c|c|c|c|c|}
\hline \multirow{2}{*}{ Гибриды (А) } & \multirow{2}{*}{$\begin{array}{c}\text { Вариант } \\
\text { обработки (C) }\end{array}$} & \multicolumn{5}{|c|}{$\begin{array}{c}\text { Число растений на единицу площади (В), } \\
\text { тыс. шт. раст. /га }\end{array}$} \\
\hline & & 25 & 35 & 45 & 55 & 65 \\
\hline \multirow{6}{*}{ Pocc 197 MB } & $\mathrm{C}_{1}$ & 4,00 & 5,03 & 5,34 & 5,80 & 6,63 \\
\hline & $\mathrm{C}_{2}$ & 4,20 & 4,60 & 4,80 & 5,33 & 6,64 \\
\hline & $\mathrm{C}_{3}$ & 4,16 & 4,95 & 5,14 & 5,26 & 6,41 \\
\hline & $\mathrm{C}_{4}$ & 3,63 & 4,59 & 5,52 & 5,43 & 5,40 \\
\hline & $\mathrm{C}_{5}$ & 4,23 & 4,66 & 5,42 & 5,05 & 6,55 \\
\hline & $\mathrm{C}_{6}$ & 3,38 & 4,61 & 5,02 & 5,31 & 7,81 \\
\hline \multirow{6}{*}{ Pocc 299 MB } & $\mathrm{C}_{1}$ & 4,54 & 6,13 & 6,74 & 6,85 & 7,73 \\
\hline & $\mathrm{C}_{2}$ & 4,64 & 5,68 & 6,33 & 6,23 & 7,07 \\
\hline & $\mathrm{C}_{3}$ & 3,98 & 6,06 & 6,31 & 6,17 & 7,06 \\
\hline & $\mathrm{C}_{4}$ & 3,99 & 5,80 & 6,23 & 6,68 & 7,18 \\
\hline & $\mathrm{C}_{5}$ & 4,50 & 5,59 & 6,06 & 6,42 & 6,05 \\
\hline & $\mathrm{C}_{6}$ & 4,45 & 5,15 & 6,22 & 6,60 & 6,36 \\
\hline \multirow{6}{*}{ СТК 175 MB } & $\mathrm{C}_{1}$ & 3,45 & 4,32 & 5,04 & 5,25 & 4,94 \\
\hline & $\mathrm{C}_{2}$ & 2,57 & 3,79 & 4,42 & 5,80 & 5,60 \\
\hline & $\mathrm{C}_{3}$ & 3,91 & 3,66 & 4,18 & 5,01 & 5,50 \\
\hline & $\mathrm{C}_{4}$ & 3,45 & 3,53 & 3,83 & 4,78 & 4,96 \\
\hline & $\mathrm{C}_{5}$ & 4,03 & 3,42 & 4,70 & 5,62 & 5,13 \\
\hline & $\mathrm{C}_{6}$ & 3,28 & 3,24 & 3,83 & 4,17 & 4,41 \\
\hline$F_{\text {факт. }}$ & \multicolumn{6}{|c|}{$\begin{array}{c}\mathrm{A}=927,60^{*} ; \mathrm{B}=1197,25^{*} ; \mathrm{C}=63,50^{*} ; \mathrm{AB}=54,57^{*} ; \\
\mathrm{AC}=26,48^{*} ; \mathrm{BC}=11,93^{*} ; \mathrm{ABC}=22,21^{*}\end{array}$} \\
\hline $\mathrm{HCP}_{05}$ & \multicolumn{6}{|c|}{$\begin{array}{c}\mathrm{A}=0,10 ; \mathrm{B}=0,07 ; \mathrm{C}=0,06 \\
\mathrm{AB}=0,15 ; \mathrm{AC}=0,14 ; \mathrm{BC}=0,15 ; \mathrm{ABC}=0,27\end{array}$} \\
\hline \multicolumn{7}{|c|}{${ }^{*}$ Среднее по фактору А: 5,17 b; 5,99 c; 4,35 a } \\
\hline \multicolumn{7}{|c|}{${ }^{*}$ Среднее по фактору В: 3,91 a; 4,76 b; 5,25 c; 5,74 db; 6,19e; } \\
\hline \multicolumn{7}{|c|}{${ }^{*}$ Среднее по фактору C: 5,47 d; 5,21 c; 5,21 c; 5,0 a; 5,19 bc; 5,95 a } \\
\hline
\end{tabular}

тыс. шт. раст./га, $\mathrm{C}_{4}$ и $\mathrm{C}_{5}$ при густоте 45,0 тыс. шт. раст./га и $\mathrm{C}_{2}$ и $\mathrm{C}_{6}$ при густоте 65,0 тыс. шт. раст./га. Причем увеличение урожайности на густотах 25,0 и 45,0 тыс. шт. /га было незначительным - 0,16-0,23 т/га и 0,8-0,18 т/га соответственно. При максимальной густоте существенную прибавку обеспечил вариант $\mathrm{C}_{6}-1,18$ т/га.

На посевах среднераннего гибрида Росс 299 МВ в условиях 2016 г. прибавка урожайности в 0,1 т/га зафиксирована только на варианте $\mathrm{C}_{2}$ при густоте стоянии растений 25,0 тыс. шт. раст./га.

Более выражено действие препарата в посевах среднепозднего гибрида СТК 175 МВ. Так в 9 вариантах из 30 выявлена прибавка урожая, из них два варианта $\left(\mathrm{C}_{3}\right.$ и $\left.\mathrm{C}_{5}\right)$ на густоте 25,0 тыс. шт. раст./га, один $\left(\mathrm{C}_{5}\right)$ на густоте 45,0 тыс. шт. раст. /га, три $\left(\mathrm{C}_{2}, \mathrm{C}_{3}, \mathrm{C}_{5}\right)$ на 55,0 тыс. шт. раст./га и три $\left(\mathrm{C}_{2} . \mathrm{C}_{3}, \mathrm{C}_{4}\right)$ при по- вышенной густоте стояния растений. На густотах 35,0 и 45,0 тыс. шт. раст./га обработка Экстрасолом не способствовала повышению урожайности зерна кукурузы.

В 2016 г. влияние факторов на изменчивость признака «урожайность зерна» составило: А $33,6 \%$; В - 47,0 \%; C - 2,13\%, а их взаимодействие: АВ - 4,28 \%; АС - 1,78 \% и ВС - 1,60\%; $\mathrm{ABC}-5,97 \%$.

Заключение. Урожайность зерна гибридов кукурузы, отличающихся по продолжительности вегетационного периода, существенно различалась по факторам А, B, С и их взаимодействию. В 2014 г. самая высокая урожайность зерна установлена у раннеспелого гибрида Росс 197 МВ, в 2015 и 2016 г. у среднераннего гибрида Росс 299 МВ. Среднепоздний гибрид СТК 175 в условиях эксперимента не реализовал потенциальную урожайность. 
Установлено, что у гибридов прослеживается тенденция увеличения урожайности зерна при возрастании числа растений на единицу площади. Урожайность зерна по фактору В изменялась от 3,23 до 7,25 т/га в 2014 г.; от 3,80 до 8,41 т/га в 2015 г.; от 3,91 до 6,19 т/га в 2016 г.

Урожайность зерна кукурузы по фактору С в 2014 г. варьировала в интервале 5,305,53 т/га. Самая высокая урожайность установлена при опрыскивании посевов в фазу 4-5 листьев $\left(\mathrm{C}_{2}\right)$, а самая низкая при обработке семян и вегетирующих растений в фазу 4-5 листьев $\left(\mathrm{C}_{5}\right)$. Урожайность зерна на варианте $\mathrm{C}_{1}$ (без обработки) составила 5,30 т/га. По критерию Дункана отличия по урожайности зерна отсутствуют между вариантами $\mathrm{C}_{1}$ и $\mathrm{C}_{6}$.

В 2015 г. эффект от применения микробиологического удобрения был более выражен на варианте $\mathrm{C}_{6}$, прибавка урожайности составила 0,48 т/га относительно контроля. В 2016 г. самая высокая урожайность зерна кукурузы установлена на контроле $\left(\mathrm{C}_{1}\right)-5,47$ т/га.

Наибольшее влияние на изменчивость признака «урожайность зерна» в 2014 и 2015 гг. оказал фактор В (густота стояния растений) 79,0 и 82,30 \% соответственно. В 2016 г. влияние фактора В было несколько ниже - 47,0 \%. Эффект других факторов в годы исследований составил: А - 0,86; 2,24; 33,6 \%; C - 0,07; 1,43; $2,13 \%$. Вклад взаимодействия факторов (АВ, AC, ВС, АВС) колебался от 0,75 до 5,97\%.

\section{СПИСОК ЛИТЕТАТУРЫ}

1. Агроэкономическая эффективность применения биопрепарата «Экстрасол» на посевах зерновой кукурузы в Нижнем Поволжье / А.П. Солодовников [и др.] // Аграрный научный журнал. - 2017. № 11. - С. 32-36.

2. Биологические особенности и технология возделывания основных полевых культур в Алтайском крае / Ф.М. Стрижова [и др.]. - Барнаул: Издво АГАУ, 2006. - 124 с.

3. Влияние удобрений и густоты стояния растений на урожайность зерна кукурузы в Лесостепной зоне Поволжья / С.А. Семина [и др.] // Аграрный научный журнал. - 2017. - № 3. - С. 25-29.

4. Доспехов Б.А. Методика полевого опыта. M., 2011. -351 c.

5. Завалин А.А. Биопрепараты, удобрения и урожай. - М.: Изд-во ВНИИА, 2005. - 302 с.

6. Кожемяков А.П., Тихонович И.А. Использование инокулянтов бобовых и биопрепаратов комплексного действия в сельском хозяйстве // Доклады Россельхозакадемии. - 1998. - № 6. - С. 7-10.

7. Кошкин Е.И. Гатаулина Е.И., Дьяков А.Б. Частная физиология полевых культур. - М.: КолосС, 2005. - 344 c.

8. Кравченко Р.В. Агробиологическое обоснование получения стабильных урожаев зерна куку- рузы в условиях степной зоны Центрального Предкавказья. - Ставрополь: Ставропольбланкиздат, 2010. - 208 c.

9. Кукуруза в Саратовской области / А.П. Царев [и др.]; Сарат. гос. с.-х. акад. - Саратов, 1996, - 152 с.

10. Методические рекомендации по проведению полевых опытов с кукурузой / сост.: Д.С. Филев [и др.]. - Днепропетровск, 1980. - 54 с.

11. Никитин С.В. Влияние элементов технологии возделывания на урожайность гибридов кукурузы в зоне неустойчивого увлажнения: автореф. дис. ... канд. с.-х. наук. - Ставрополь, 2012. - 22 с.

12. Оказова 3.П., Мамиев Д.М., Тедеева А.А. О путях повышения урожайности кукурузы в условиях лесостепной зоны РСО-Алания // Современные проблемы науки и образования. - 2015. № 5. - С. 695.

13. Применение биопрепарата Экстрасол и микроудобрения Кристалон на посевах кукурузы / Д.М. Мамиев [и др.] / / Земледелие. - 2011. № 2. - С. 29-31.

14. Семина С.А., Надежкин С.М. Формирование высокопродуктивных агроценозов кукурузы в лесостепи Среднего Поволжья. - Пенза, 2008. - 148 с.

15. Список пестицидов и агрохимикатов разрешенных к применению на территории Российской Федерации. - 2017. - 792 с. - Режим доступа: dokipedia.ru>pdf/5161888.

16. Стулин А.Ф. Продуктивность гибридов кукурузы в зависимости от густоты стояния и уровня минерального питания / / Кукуруза и сорго. - 2009. № $1 .-$ C. $4-5$.

17. Тедеева А.А., Мамиев Д.М., Оказова З.П. Влияние минеральных удобрений на продуктивность посевов гороха в условиях лесостепной зоны РСО-Алания // Современные проблемы науки и образования.- 2015. - № 2(58).- С. 750.

18. Francis $A$. The iripsacinae: an interdisciplinary review of maize (Zea mays) and its relatives // Acta Bot. Fenn., 1990, Vol. 140: 1-51.

19. www. bisolbiplus. Ru.

Гудова Людмила Александровна, канд. с.-х. наук, ведущий научный сотрудник отдела кукурузы и трав, РосНИИСК «Россорго». Россия.

410050, г. Саратов, ул. 1-й Институтский проезд, 4.

Тел.: 89271242886; e-mail: abelia77@mail.ru.

Жужукин Валерий Иванович, $\partial-p$ c.- $x$. наук, проф. кафедры «Растениеводство, селекция и генетика», Саратовский государственный аграрный университет имени Н.И. Вавилова, Россия.

410012, г. Саратов, Театральная пл., 1.

Тел.: (8452) 26-16-88.

Зайцев Сергей Александрович, канд. с.-х. наук, ведущий научный сотрудник отдела кукурузы и трав, РосНИИСК «Россорго». Россия.

Волков Дмитрий Петрович, главный научный сотрудник отдела кукурузы и трав, РосНИИСК «Россорго». Россия.

410050, 2. Саратов, ул. 1-й Институтский проезд, 4.

Тел.: 89271242886; e-mail: abelia77@mail.ru. 
Гераскина Анастасия Александровна, магистр, Саратовский государственный аграрный университет имени Н.И. Вавилова. Россия.

410012, г. Саратов, Театральная пл., 1.

Тел.: (8452) 26-16-88.
Ключевые слова: гибриды кукурузы; микробиологическое удобрение; урожайность зерна; густота стояния растений.

\title{
THE EFFECT OF MICROBIOLOGICAL FERTILIZER AND PLANT STAND ON THE YIELD OF CORN HY- BRIDS GRAIN IN THE LOWER VOLGA REGION
}

Gudova Lyudmila Aleksandrovna, Candidate of Agricultural Sciences, Leading Researcher, Russian Research Institute for Sorghum and Maize "Rossorgo". Russia.

Zhuzhukin Valeriy Ivanovich, Doctor of Agricultural Sciences, Professor, of the chair "Crop production, Selection and Genetics", Saratov State Agrarian University named after N.I. Vavilov. Russia.

Zaytsev Sergey Aleksandrovich, Candidate of Agricultural Sciences, Leading Researcher, Russian Research Institute for Sorghum and Maize "Rossorgo". Russia.

Volkov Dmitriy Petrovich, Senior Researcher, Russian Research Institute for Sorghum and Maize "Rossorgo". Russia.

Geraskina Anastasiya Aleksandrovna, Magister, Saratov State Agrarian University named after N.I. Vavilov. Russia.

Keywords: maize hybrids; microbiological fertilizer; grain yield; plant stand.

The results of studies of the three-factor experiment, which allows determining the effects of the microbiological fertilizer Extrasol (factor C) and plant stand (factor B) on the yield of corn hybrids (factor A), are presented. It was established that in 2014, an early ripening hybrid Ross 197 MW had a higher average yield - 5.46 t/ha. In 2015 and 2016, middle-early ripening hybrid Ross $299 \mathrm{MW}$ was more productive -6.85 and $5.97 \mathrm{t} / \mathrm{ha}$ respectively. During the experiment, middle-late hybrid STK 175MV did not realize the potential yield due to lack of moisture during the growing season. Hybrids have a tendency to increase grain yield with an increase in the number of plants per unit area. The grain yield by factor $B$ in 2014 was 3.23-7.25 t/ha; in 2015-3,80-8,41 t/ha; in 2016-3.91-6.19t/ha. The variability of the sign "grain yield" in 2014 and 2015 was influenced by factor B (plant stand) - 79.0 and $82.30 \%$, respectively. In 2016, the influence of factor $B$ was slightly lower $-47.0 \%$, but at the same time the influence of factor A (hybrid) increased - $33.6 \%$.

удк 633.15:631.527

\section{ОЦЕНКА ЭФФЕКТИВНОСТИ ГАПЛОИНДУКТОРА кУкУрУзЫ ЗМс-п}

\author{
ГУТОРОВА Ольга Валентиновна, Саратовский национальный исследовательский \\ государственный университет имени Н.Г. Чернышевского
}

ЮдАКОВА Ольга Ивановна, Саратовский нацииональый исследовательский государственный университет имени Н.Г. Чернышевского

ЗАЙЦЕВ Сергей Александрович, Российский научно-исследовательский и проектнотехнологический институт сорго и кукурузы

Приведены результаты оценки способности киндукиии образования гаплоидов семей (потомство одного початка) создаваемой гаплоиндуцирующей линии кукурузы ЗМС-П. В качестве материнских форм использовали растения 53 гибридов и одной сортопопулящии, в качестве отцовских форм - растения 21 семъи линии ЗМС-П. С помощъю метода генетического маркирования был проведен отбор зерновок с гаплоидным зародышем среди гибридных семян. Частота образования гаплоидов в полученном гибридном потомстве при скрещивании с разными материнскими формами варьировала от 0 до 15,8\%. Средняя частота гаплоиндукиии по семъям варъировала от 1,3 до 7,0 \%. Средняя частота гаплоиндукиии составила 4,8 1,7 \%. Таким образом, линия ЗМС-П является эффективным гаплоиндуктором, который можно использовать для массового получения гаплоидов и ускоренного создания на их основе новых гомозиготных линий кукурузы.

Введение. Ценным исходным материалом для создания высокогетерозисных гибридов кукурузы являются гомозиготные линии. Для создания их традиционным методом самоопыления требуется не менее 6 лет работы. Использование в селекции гаплоидии in vivo и in vitro ускоряет процесс выведения таких линий до двух лет. В основе данных технологий лежит индукция развития гаплоидов, которые далее подвергают диплоидизации. В случае ее успешного прохождения, фертильные диплоидизированные растения самоопыляют и получают первое поколение новой гомозиготной линии [4, 6-8]. Одним 